\title{
URBAN SECURITY, LOOKING FOR THE NEW PARADIGM
}

\author{
André INÁCI032 \\ CEDIS, Universidade Nova Lisboa
}

"Cities are the greenhouses of humanity, the place where human potential is developed to the zenith of excellence and variety. (...) They are arenas of ambition and conquest"

Myron Magnet

\begin{abstract}
The current moment is marked by a process of socioeconomic integration, based on strong inter-spatial connections that lead to a model of society that could be called a "global village". On the other hand, it is also fractional, exposing inequalities in opportunities, socioeconomic divisions, and poor redistribution of wealth and constant violations of human rights. This global reality has a local emporium in the great urban metropolis, where the multiple races, ethnicities, cultures and traditions converge and do not always interact in the best way, creating a mix that lacks social policies that meet human dignity, allowing identification with aims and objectives of the neighbourhood, reflecting an organized urban culture, developed in favor of citizens and with which they identify and in which they wish to participate. The great challenges that we face today in the social dimension, when we approach it from the perspective of security, are political and legal (insufficient) and not technological. In today's societies, it is essential to find answers that are immediately effective and of low cost, that do not restrict the area of individual freedom protected by the rule of law, this requires constant monitoring, always within the limits of proportion and respect for the Human Rights.
\end{abstract}

Keywords: urban security, human dignity, human rights, risk society, threats

\section{Introduction}

The present model of society is marked by the "globalization", which is a process of socioeconomic integration, that includes nations, cultures, states and continents, sustaining the digital revolution, utilizing the technological advance and the development of the communications and transportation networks, providing strong interspatial connections which leads to a society model that could be referred as "global village", in a very simplified way of referring to such a complex phenomenon but that resembles the proximity of the relation.

However, globalization didn't come with advantages only. As it speeds up and multiplies, this socioeconomic phenomenon illustrates a double strand. If, on one hand, its homogenizing,

32 Contact email: andrenacio@gmail.com. 
uniforming social behaviours, marking tendencies and potentializing a democratic access to live time information, on the other hand, it is also fractional, exposing inequalities of opportunities, socioeconomic cleavages, the wealth redistribution, the constants violations of the Human Rights practised by states and, mostly, by big international economical groups.

In parallel, the postmodern era is characterized by the lack of trust do to the "big narratives" of the society, tearing them apart and socially condemning those who defend them. The technology, the IT in particular, contribute to the masses, in favour of politic, economic and groups interests. By promoting mobility, globalization contributes to the swift dissemination of pandemics.

Therefore, globalization generated new "risks" and new "hazards", that will shake the foundations of the State of Social Law (Miranda 2013), leading to the modern concept of global risk society (Pinto 2016), in which the security - concept implicit to all societies - that emerges like an idea of lesser "vulnerability" to the "threats" that social evolution brought (ibid.), achieving a new level.

This global reality has a local emporium in the bigger urban metropolis, where they converge and, not always in the best way, interact with multiple races, ethnicities, cultures and crafts, originating a "culture stew" that lacks of social politics that attend the human dignity, devolved based on an integration with no paternalisms strategy, belonging to a collective, of neighbourhood, this is, identifying with ends and objectives of the neighbourhood, reflecting an urban organized culture, developed in favour of the citizens and with which the same identify and want to participate in.

\section{Security: conceptualization attempt}

Globalization is characterized by "events speed", generating massive unbalances in the middle of societies, destabilizing and exposing authoritarian regimes, but affecting the Social Law State model too. According to Teixeira (2016) the international scene is currently crossed by two parallel and contradictory dynamics: the Vestefália dynamic and the Globalization dynamic. The first, of state-centred nature, settles the states and their relations, operating according to an interstate logic. The second crosses, transcends and often subverts the state borders and operates according to a transnational logic.

Simultaneously, the Security Internal System archetype still vastly present in European space, enhanced in its genesis of geopolitics and geostrategic directives which are outdated, date back to the Cold-War scenario, of terrorist organizations actions inspired ideologically in which the organized crime still couldn't reach other nations besides their own, and the cyber threat was inexistent (Inácio 2018).

This comes from gradually and changes due to a series of apparently disconnected events, but that contribute to the regular status-quo, being the liberation of the financial markets and primary needs, conjugated with the end of the soviet blockade, in 1989, adding to the already mentioned ongoing globalization process, represents a Humanity History conjecture that leads to the change of all paradigms (Glenny, 2008).

In the current global socioeconomic spectre, the open democratic society, based on guaranties forced by the State of Law, defined as a "Risk Society", on which the proportion of risks, threats and challenges demands fast response strategies, innovative and focused on a global level. The 
threats that hover the current socio-political models of organization are multiple, which are intrinsically dependent of critical infrastructures as transport networks of energy and communication, demanding the adequate capacity of prevention and reaction. Example of such concerns of energetic security and communication networks, as well as the ecosystem prevention, are areas where offenses have become more common and go beyond more state borders where the effects have been felt. Adding to even more complex ways of crime, like the increment of the terrorist phenomenon, with the sub consequent susceptibility of occurring attempts using toxic gas or poisoning the essential needs.

More recently two new phenomena contribute to the insecurity feeling, one of pandemic nature, caused by the COVID-19 virus, the other has germinating in the recent years, of a sociological nature, growing in a global mistrust movement do to the "big narratives" of the society (Murray 2018), for which the minorities more than enforcing their rights, aim to impose them in an anti-democratic way, replacing dogmas for new ones, in an authentic imposition of a dictatorship of the minorities where "either you are in favour, or against".

Thus, the multicultural and globalized XXI century societies, the "Mutant Concept" security, evolves in the face of the risks and threats, as an indispensable analytic subject to all independent societies of the geographic regions, continents, ethnicities, ideologies, "security forces" models and the social states organization archetypes, generating a quadrature of the circle that, in terms of Humanity History conjecturer, leads to the inevitable change of all paradigms.

Being a holistic concept, security, demands specialized areas in parallel, separating the safety and security, as well as specify the development of the homeland security, urban security, transports security, etc. According to Guedes (2010) "the slightest bibliography scrutiny and the countless recent performances shows it as it is: 'securitize' as lost its importance almost if by stretch. The current definition of security has changed. On one hand, it has lost the close to exclusive public, national and military dimension. The concept of security covers the public institutions actions and commitment, but also of private, local and civil societies in a more ample way - as well as the supranational institutes and organizations, either they are built by close by states, intergovernmental entities or others of supranational nature.

Therefore, we are refer to the already mentioned Risk Society concept (Beck 1992), globalizing all the different conducts that are characterized by their invisibility, unpredictability, unlimited potentiality, non-recognition of borders, creeds or races, and, of which, we all are possible agents and/or victims.

\section{Urban security in a perspective reflexion}

The urban security is the most obvious paradigm to transmutation form the concept of security and the universe it covers. The big metropolises are constituted by their main lab, where the bi socioeconomically changes occur and from there propagate to a global scale (Magnet 2000). Adding to a community that is constituted by a diversity of cultures, religions and creeds, that have to coexist with the social differences they possess, in permanent conflict - dignified and emancipator - in order to defend the right to individuality and being a member of a differentiated group, the 
cities are also the liberty realm, providing the opportunity to reinvent, choose ones friends, to promote yourself, enjoying the privacy and the anonymity, to consider new ideas, however, their mental labs susceptible to create danger thoughts and sub consequently deviant behaviours.

The unequal opportunities, the proliferation of information access and, mostly, the absence of insertion politics, create an insecurity feeling, from the second-class citizen, in an expressive community layer making it vulnerable and potentially dangerous, directly or by induction. The current fracturing causes of society, creating conflicts of culture genesis on companies, schools and in the centre of families, where the right to social justice and identity politics transmute from a fight for recognition of rights to a social model where those who don't think and act according to these models, are punish and discriminated, leading them to a global "minorities despotism", where following a Mediterranean diet, being heterosexual or attend to a certain show, has become an object of censorship, social conviction, professional persecution and vote to ostracism, contributing to the urban insecurity feeling.

However, the most memorable example and that achieves currently its maximum exponent of the bad (when not, the absence of) public politics of integration, it's the UE bad response to the migration crises. In fact, the measures adopted in the ambit of PESC have been revealing insufficient and of scarce efficiency, the same happening with the public positions of the principal politics involved, whose narratives present a strong demagogic component, with no solutions and that won't tranquilize the public opinion, contributing in a way to the human security disruption, when it comes to the migrant integration (Inácio et al 2018).

Part of the response to the question going through the "European Migration Minimum Standards (EMMS)" 33 thought on the UE context that concedes the states, intuitions and civil society, the minimum principles to international migration frame to the light of human security, something that became clearly secondary during the last years of ruling the migrations in Europe and that it's important to bring to the local reality, on an urban level. Actually, gaps keep existing in the effectuation that lead to an inadequacy of the protection of the human dignity in this domain, imposing to a revision of the migration system at a global, regional and national scale, which reflexes will be felt, naturally, on a local level.

Simultaneously, with the current realities, there are still urban security problems as old as cities. In fact, public health, education, housing, integration of minorities, economic activities, misdemeanour and transport networks are topics that require an answer since the first "polis". They have been there all along, and keep needing answers, regardless of the new necessities resulting from the terrorist threat of a salaphist global nature, organized crime, xenophobe movements, pollution, tourism increment, the growth of disintegrated migrant communities as well as resulting matter of energy and communication network and, at last the militancy of the identity. The complex multiphase picture of risks, threats and opportunities inherent to the big metropolis leads to the necessity of altering the urban security paradigm. Such necessity was felt for the first time in the ninety's decade of the past century in the USA, when the cities like

33 Available at https://ec.europa.eu/home-affairs/what-we-do/networks/european_migration_network/glossary_search/minimum-standards_en 
New York, Philadelphia and Los Angeles faced serous stagnation, deficit and misdemeanour, demanding prevention measures and quick and adequate responses (ibid).

Thus new reaction politics where developed, focusing on four convergent vectors, which goal still currently maintains the same, if not, let's see:

Crime Reduction - it was demanded, as it is today, the capability of proper prevention and reaction by the Administration, namely ending the victimless crimes impunity (graffiti, using public transports without a ticket, etc...) as well as the feeling that one can prevaricate without punishment (implies the ability to rapidly investigate and sentence). For this to succeed, it is demanded police patrols and firm action in the maintenance of the order and prevention of public matrimony. In parallel, it is important to identify the organized crime structures, together with the Information Services, acting accordingly.

Integration - Integration is the genesis of prevention in the medium and long term, and for that it is important to make family cohesion policies thrive, a decisive contribution to the reduction of marginality. In addition, there is a need to reform social assistance policies in general and in particular, inclusion, since no one has the right to be helped unconditionally, everyone has to contribute. Being a citizen confers rights but imposes duties face to the public cause, because, as criminology has already shown, community work contributes to the development of self-esteem and dignifies human beings (Cusson 2011). Raising awareness of citizenship is also a determining factor in a democratic society and must begin in pre-school education. Meanwhile, professional training (supposed to be a tool for integrating those who do not want / can complete higher education) is not a solution itself, it is also important to complement it with accompanying policies, encouraging and assisting in the search and maintenance of jobs. Finally, the individual must feel that he is part of the community and a relevant element, in his own way, for its effectiveness.

Reinvention of the municipal executive - Exponentiation of its effectiveness, which implies on the part of the Mayors the defence of the interest of the Polis and not of political / party conveniences or, at the service of economic groups. The high number of consultants (of party origin) and municipal public companies, constitute the breeding ground that leads to an increase in promiscuity in public decision making the city economically unviable. The solution is to reduce the number of "monthly pass" as well as the privatization of some municipal services, namely road repair works, collection and treatment of solid waste and management of transport fleets. Finally, rates and taxes have to be adjusted in order to make it attractive for large companies to operate there, creating new and lasting jobs.

Reform of the education system - Education for citizenship is urgent, adopting a model based on a common branch of core curricular units, complemented by optional subjects, appealing to different sections of the community, also mobilizing migrant communities to study through identification with the education model. Naturally, the content must be appealing and integrating, fostering pride in belonging to the global group, without losing the pride of a differentiated subgroup, with a history and a culture. Finally, it is important that the restructuring of the system takes place under strict quality standards, contemplating a serious evaluation system, with the responsibility of teachers, students and guardians. 
To these four vectors, as a result of increasing mobility, we would add a fifth, Transports - The evolution of the global risk and threat framework has shown that the world is not immune to a set of multiple and rampant threats, which are expanded by the circulation of people. Thus, it is in the field of public health as well as in more or less structured criminal typologies, requiring a concerted response in the fields of prevention and reaction. Covering a wide area of concern, transport security must, currently, ensure the necessary balance between the rights to free movement and the freedom and security of citizens, while at the same time addressing environmental and economic security, and must also consider a different kind of risks that range from the common crime to the terrorist threat, including cybercrime, requiring, at the same time, the necessary proportionality in the measures to be taken, in order to ensure that they do not become excessively intrusive, which would generate another form of insecurity, in addition to immense discomfort felt by the passenger. Therefore, security measures must be implemented according to a risk analysis facing the level of threat, of which the most advanced example is the current civil aviation security regime. Collectively, the transport sector is part of the security of society, and must be an integral part of the security policies to be developed. The future of transportation will be heavily influenced by security considerations (Inácio and Geraldes 2019).

\section{Urban security: a perspective reflexion}

In the current model of society, security is not a given commodity, since the new framework of Risks and Threats, a transmutation in the architecture of security is required, which affects the concept itself, with primary prevention and public security taking on enhanced relevance, in the defence of the Fundamental Right to Security by the collective, while guaranteeing the defence of the Fundamental Rights of the individual citizen.

Counties must optimize their public security policies, improve their prevention and reaction mechanisms, in democratic balance, under constitutionally established limits. Buildings are built by the foundations, so it is urgent to involve the civil society, acting at the local community level (identifying and fighting alongside the troubled residents, in an integrated and integrating way).

Smart Cities are a reality! Technology contributes in a decisive way to real and / or perceived security, and allows to anticipate some risks inherent to its own evolution, (however, public debate is necessary, enhancing clarification and consequently the confidence of the citizen).

Announcing public policies is not enough, it is necessary to implement them effectively. Urban Security goes through a correct and timely cartography, using analysis tools that allow decision support, aiming at situational and social prevention strategies. It is crucial to maintain order in the public space, stimulating and (if necessary), imposing social behaviours that respect this order, keeping streets and gardens clean and cared for, sponsoring the development of housing, education and culture. The architectural and cultural heritage must be especially preserved because a city is its history. The stimulus that the city provokes in the intellect and in the entrepreneurial spirit make the cities indispensable.

The great challenges that we face today in the social dimension when we approach it from the perspective of security, are political and law (insufficiency of) and not technological. In today's 
societies, it is essential to find answers that are immediately effective and have a low cost, that do not restrict the area of individual freedom protected by the State of Law, which requires constant identification, monitorization, and prevention and reaction capability, always within the proportion limits.

Finally, it is important to be aware of the potential risks inherent in the protection of human rights, a matter in which GDPR constitutes itself as a security instrument for citizens in exposure to the digital world, namely acting as a "driver" in security policies, in guaranteeing privacy.

\section{References}

1. Beck Ulrich (1992), Risk Society: Towards a New Modernity, London: Sage.

2. Cusson, Maurice (2011), La Criminologie, Hachette Education.

3. Glenny Misha (2009), McMafia: A Journey Through the Global Criminal Underworld, London: Vintage.

4. Guedes, Armando Marques e Elias, Luís (2010), Controlos Remotos, Almedina.

5. Inácio, André (2018), A Sociedade de Risco, as IT e o Exercício da Liberdade em Segurança. Chapter in Modelos Preditivos e Segurança Pública, Porto: Fronteira do Caos.

6. Inácio, André and Geraldes, Ana (2019). Transports Security: contributions for the Security of the Trans-European Transport Network, Chapter in Security is a Crossroad, New Tools for a New Challengers, New York: Nova Science Publishers.

7. Inácio, André et al. (2018) "Population Dynamics Risks and Opportunities", conference paper presented at International Scientific Conference Migrant and Refugee Crisis in a Globalised Word: Responsibilities and Responses, Ohrid, 5-7 September 2018.

8. Inácio, André (2016), "A Longa Marcha - Da Margem Sul do Mediterrâneo à Europa", Revista Segurança e Defesa, No 133, Lisboa.

9. Magnet, Myron (2000), The Millennial City, NY: The Manhattan Institute.

10. Miranda, Jorge (2013), Manual de Direitos Fundamentais, Tomo VI, $4^{\mathrm{a}}$ Edição. Coimbra: Coimbra Editora.

11. Murray, Douglas (2018), The Madness of Crowds. Gende, Race and Identity, Blubsburing Publishing.

12. Pinto, M. Serafim (2016), Segurança, a Queda do Paradigma Original. Fronteira do Caos, Editores, Porto.

13. TeixeiraE, Nuno Severiano (2016), "Quem governa o Mundo", XXI, TER OPINIÃO, No. 6, Fundação Francisco Manuel dos Santos, semestral. Lisboa. 